MR i magi ng as predict or of del ayed post t r aumat i c cer ebral hemor r hage

\begin{tabular}{|l|l|}
\hline 著者 & 田中 篤太郎 \\
\hline 杂倠志名 & 浜松医科大学学報. 学位授与記録 \\
\hline 巻 & 8 \\
\hline ページ & $51-52$ \\
\hline 発行年 & $1990-12-07$ \\
\hline URL & ht t p: //hdl . handl e. net $/ 10271 / 1371$ \\
\hline
\end{tabular}


学位論文の内容の要旨及び論文審查の結果の要旨

\begin{tabular}{|c|c|c|l|}
\hline 学位記番号 & 医博論第 94 号 & 学位授与年月日 & 平成 2 年 12 月 7 日 \\
\hline 氏 名 & 中 田篤太郎 \\
\hline 論文題目 & $\begin{array}{l}\text { MR imaging as predictor of delayed posttraumatic cerebral hemorrhage } \\
\text { (MRI による遅延型外傷性脳内出血の予測) }\end{array}$ \\
\end{tabular}




\section{医学博士 田中第太郎}

論文题目

MR imaging as predictor of delayed posttraumatic cerebral hemorrhage

（MRI に上る遅延型外㮩性脳内出血の予測）

\section{論 文の内容の要旨}

（緒言）コンピューター断層撮影（以下、CTという）装直の普及以後、外賃後早期のCTで脳実啠内に異 常が見られないが、その後のCTで脳実侯内に出血性変化が見られる症例が多く存在することか報告された。 これは一般的に遅延型外傷性脳内出血または血腫（以下、DTICHという）之言われる。DTICHは予後不良と なることも多く、その予测がいろいろ試みられたが困難であった。一方、磁気共鳴断層撮影（以下、MRI いう）装置の出現によって、CTで診断困難な様々な頭蓋内の病態が診断されるようになった。しかし、急性 期頭部外傷へのMRIの応用の報告は少なく、今までDTICHの診断に用いられたことはなかった。我々は頭部 外伤の超早期例でMRIのT2強調画像を摄像し、DTICHの予測に成功したので報告する。

（方法及ひ対象）1986年 6 月より1987年 2 月までに、聖隷三方原病院に入院した頭部外傷患者は42名で ある。これらの患者のうち 6 名で初回CTで脳実質内に異常所見を認めないが脳挫煷の疑いがもたれた。それ は受部時の神経学的症状が初回CTから予想されるものより悪いか、またはすでに初回CTで頭蓋内かつ脳実質 外に出血性変化が見られたためである。これらの患者では初回CT後すぐにMRIのT2強調画像が撮像された。 MRIのパルスシークエンスはスピンエコー法TR2000msec、TE150msecをT2強調画像として使用した。我々は、 Gudemanらの基準より笽しく、初回CTで脳実質内に異常所見を認めず、その後のCTで高吸収領域が現れたと きのみこれをDTICH之眕断した。

（結果）上記の6 例の患者の内、4例が我々の㟝断基準でDTICHと診断された。これらの症例では初回 CTでは脳実質内に異常所見は見られず、その直後のMRIのT2強調画像で脳夷質内に高信号領域が見られた。 これらの領域は受伤部位より coup injuryまたはcontra-coup injuryに相当すると考えられる。2回目のCT で、これらの部位において出血性変化が見られた。

2 例では、初回CT及びMI もも脳実質内に異常所見が見られず、その後のCTでも出血性变化が見られなか った。

（考察）Snowらは 5 例の頭部外賃の患者においてCTが正常だが林で非出血性の脳挫倁が発見されたこ 亡を報告し、MRIの優位性を強調した。Hanらは脳挫賃の症例において、T2強調画像が脳挫賃部位を高信号 領域としてはっきりと同定できることを報告し、これは浮腫による水分含有垔の增加によると説明している。 しかし、これらの報告では主に亜急性期以降の脳挫倛に於けるMRIの優位性を指摘したに留まり、受賃後の 脳の経時的変化には注意が払われていない。

Smi thらの奏験的な脳挫伤の研究によれば、外伤後 5-6 分で既に血管周囲の血液漏出亡複数のpetechia が観察され、その周囲の脳の表面の浮腫と腫脹は15分以内に観察された。同様に有賀らはDTICHの実験的研 究において、外賃後 5 分以内に複数のpetechiaが光顕的に認められ、その後これらは增大し、30分後の光顥 像では既に間質の水の增加を伴うことを報告した。

我々が予測し得たDTICHの症例で、CTは急性期の脳挫㩐部位における水分含有量の增加をX線吸収率の变 化として描出し得なかった。しかし、MRIのT2強調画像はそれを高信号領域として捉えたと考えられた。つ まりCTでは出血自体は本来高吸収域になり、その周囲の浮腫は低吸収域になるへきである。ところが、受偒 後早期では、これらの小出血はCTの空間分解能より小さく、複数の小出血とその周囲の浮腫の集族した脳挫 傷はCTで等吸収域として現れるため、同定を困難にしていると考えられる。そして、この様な早期の脳挫偒 の病態は、MRIのT2強調画像によって、T2值の延長として高信号領域に捉えることができる。 


\section{論文查の結果の要旨}

従来、脳外㩐直後に神経学的症状が存在するのに、CTでは対応した所見が得られず、その後の経過観察CT で脳実質内に出血性变化を認めるDelayed Traumatic Intra-Cerebral Hemorrhage (DTICH) の誩断は容易で

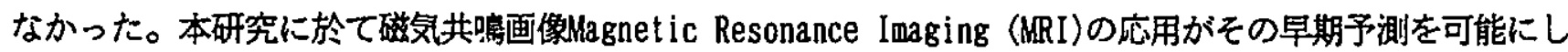
た。

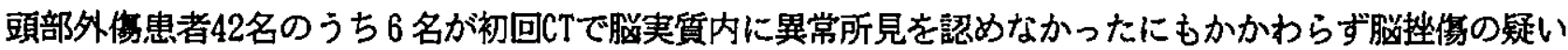
を持たれ、その後のCTで高吸収領域の認められた 4 名がDTICHの部断を受けた。この 4 名のDTICHを対象に 行ったMRI T2強調画像で脳夷質内に高信号領域が見られ、2回目に行ったCTの出血性变化の部位と一致して いた。他の 2 名では、その後のCTで出血性変化も認められず、神経学的欠落もなく退院した。

本研究で特記すべきことは、脳外傷 2 時間以内にCT摄影され、それに引続きMRIのT2强調画像が検査され、 脳挫傷による脳実質の变化を客観的に描出し得たことである。このことは0.02テスラの低磁場で険査を行い、 対象症例数は少ないが、DTICH の彭断には全例成功しており、MRIの有用性を示哇するものであった。

この発表に引続き関連事項として以下の質疑討論がなされた。

\section{䆩問事項}

1. 骨折を伴う頭部外甥のCT診断

2. 脳出血のCr坅断

3. 脳挫稘の病態生理

4. 脳挫賃のMRI影断

5. T2強調画像の意義

6. 実験的脳浮腫の病理像

7. 早期病態把挜に対するCTの限界

8. 時間的観察によるMRIの有利性

9. Glasgow Coma Scale分類について

10. 受賃直後のMRI検查の困難性

以上の質問に対する申請者の解答はおおむね適切であり、発表内容も新知見を含み、学位論文としての水、 準に達しているものと全員一致で判定した。

論文審查担当者

主査教授 金子昌 生

副査 教授川名 悦 郎副查教授藤瀨裕

副查 助教授 高 橋 元一郎. 副查 助教授 龍 浩 志 